\title{
Multiplicity of ammonium uptake systems in Corynebacterium glutamicum: role of Amt and AmtB
}

\author{
Jana Meier-Wagner, Lars Nolden, Marc Jakoby, $\uparrow$ Ruth Siewe, $\neq$ \\ Reinhard Krämer and Andreas Burkovski
}

Institut für Biochemie der Universität zu Köln, Zülpicher-Str. 47, D-50674 Köln, Germany
Author for correspondence: Andreas Burkovski. Tel: +49 221470 6472. Fax: +49 2214705091. e-mail: a.burkovski@uni-koeln.de

In Corynebacterium glutamicum, a Gram-positive soil bacterium widely used in the industrial production of amino acids, two genes encoding (putative) ammonium uptake carriers have been described. The isolation of amt was the first report of the sequence of a gene encoding a bacterial ammonium uptake system combined with the characterization of the corresponding protein. Recently, a second amt gene, amtB, with so far unknown function, was isolated. The isolation of this gene and the suggestion of a new concept for ammonium acquisition prompted the reinvestigation of ammonium transport in C. glutamicum. In this study it is shown that Amt mediates uptake of (methyl)ammonium into the cell with high affinity and strictly depending on the membrane potential. As shown by the determination of $K_{m}$ at different pH values, ammonium/methylammonium, but not ammonia/methylamine, are substrates of Amt. AmtB exclusively accepts ammonium as a transport substrate. In addition, hints of another, until now unknown, low-affinity, ammonium-specific uptake system were found.

Keywords: ammonium transport, Corynebacterium glutamicum, glutamine synthetase

\section{INTRODUCTION}

Most micro-organisms use ammonium $\left(\mathrm{NH}_{4}^{+}\right)$as the preferred nitrogen source. Although its uncharged form ammonia $\left(\mathrm{NH}_{3}\right)$ is highly membrane-permeable, energydependent transport systems for ammonium have been described in many bacteria (for a review, see Kleiner, 1993). Usually these carriers are inhibited by glutamine or its analogues (Kleiner \& Castorph, 1982; Jayakumar et al., 1986). It is proposed that the intracellular pool of this amino acid directly reflects the nitrogen supply of the cell, and therefore regulation ensures that ammonium uptake activity corresponds exactly to the requirements of the organism. In addition, synthesis of ammonium carriers is regulated by the availability of ammonium itself (Kleiner, 1985). As pointed out by

\footnotetext{
†Present address: Max-Planck-Institut für Züchtungsforschung, Carl-vonLinné-Weg 10, D-50829 Köln, Germany.

$\ddagger$ Present address: PerkinElmer Life Sciences/Berthold, Postfach 100163, D-75312 Bad Wildbad, Germany.

Abbreviation: CCCP, carbonyl cyanide $m$-chlorophenylhydrazone.
}

Kleiner (1995), intracellular ammonium accumulation by an uptake system may create an energy-wasting futile cycle, in which energy-dependent uptake is counteracted by diffusion of ammonia out of the cell. Thus, repression of carrier synthesis under conditions of sufficient nitrogen supply ensures that energy is expended for ammonium uptake only when cells are starving for nitrogen.

In contrast to this model of an energy-dependent, membrane-potential-driven ammonium transport, proposed for a variety of ammonium uptake systems in bacteria and in plants (for reviews, see Kleiner, 1993; von Wirén et al., 2000), a different concept of ammonium acquisition was suggested recently (Soupene et al., 1998). It was proposed that $\mathrm{AmtB} / \mathrm{Mep}$ proteins simply increase the rate of equilibration of uncharged ammonia across the cytoplasmic membrane rather than actively transporting and accumulating ammonium.

In Corynebacterium glutamicum, a Gram-positive soil bacterium widely used in the industrial production of amino acids, two genes encoding (putative) ammonium uptake carriers have been described. The isolation of amt (Siewe et al., 1996) was the first report of the 
sequence of a gene encoding a bacterial ammonium uptake system combined with the characterization of the corresponding protein. Recently, a second amt gene with so far unknown function was isolated. This gene was originally designated amtP, for amt paralogue (Jakoby et al., 1999). Based on a great number of homologues cloned in different bacteria, on sequence similarity analyses and on its genetic organization, this system is now designated amtB (Jakoby et al., 2000). The isolation of the amtB gene and the new model proposed for the mechanism of ammonium uptake (Soupene et al., 1998) prompted us to reinvestigate (methyl)ammonium uptake in C. glutamicum.

\section{METHODS}

Bacterial strains, plasmids and growth conditions. Strains and plasmids used in this study are listed in Table 1. Bacteria were routinely grown in Luria-Bertani (LB) medium (Sambrook et al., 1989) at $30^{\circ} \mathrm{C}$ (C. glutamicum) or $37^{\circ} \mathrm{C}$ (Escherichia coli). If appropriate, antibiotics were added at standard concentrations (Ausubel et al., 1987); LB medium for C. glutamicum strains was supplemented with $2 \%$ glucose (final concentration). To study the effects of nitrogen starvation under highly comparable conditions, a standard inoculation scheme was applied (Jakoby et al., 2000). A fresh C. glutamicum culture in LB medium was used to inoculate minimal medium (Keilhauer et al., 1993) with an excess of nitrogen source (500 $\mathrm{mM}$ ammonium) for overnight growth. This culture, with an overnight $\mathrm{OD}_{600}$ of approximately 25-30, was used to inoculate fresh minimal medium to an $\mathrm{OD}_{600}$ of approximately $0 \cdot 5$, and cells were grown until the exponential-growth phase was reached $\left(\mathrm{OD}_{600}\right.$ approx. $\left.4-5\right)$. To induce nitrogen starvation, cells were harvested by centrifugation and the pellet was resuspended in and transferred to prewarmed minimal medium without nitrogen source. The nitrogen-deprived cells were incubated at $30^{\circ} \mathrm{C}$ under aeration.

Determination of methylammonium uptake. For measurement of methylammonium uptake, cells were resuspended in minimal medium without nitrogen source to a final $\mathrm{OD}_{600}$ of 3-4 for the wild-type or 10 for amt deletion strain MJ2-38. After $3 \mathrm{~h}$ nitrogen deprivation, uptake was started by the addition of $100 \mu \mathrm{M}$ (Amt) or $1 \mathrm{mM}$ (AmtB) ${ }^{14} \mathrm{C}$-labelled methylammonium $(2.5 \mathrm{kBq})$. Samples were taken at $15 \mathrm{~s}$ time

Table 1. Strains and plasmids used in this study

\begin{tabular}{|c|c|c|}
\hline Strain/plasmid & Relevant genotype/description & Reference/source \\
\hline \multicolumn{3}{|l|}{$\begin{array}{l}\text { C. } \text { glutamicum } \\
\text { strains }\end{array}$} \\
\hline ATCC 13032 & Wild-type & Abe et al. (1967) \\
\hline LN-1.1 & $\Delta a m t B$ & This study \\
\hline LN-1.2 & $\Delta a m t \Delta a m t B$ & This study \\
\hline MJ2-38 & $\Delta a m t$ & This study \\
\hline MJ4-26 & $\Delta g \ln A$ & Jakoby et al. (1997) \\
\hline \multicolumn{3}{|l|}{ E. coli strains } \\
\hline DH5 $5 m c r$ & $\begin{array}{l}\text { supE44 hsdR17 recA1 endA1 gyrA96 thi1 relA morA } \\
\Delta(m r r-h s d R M S-m c r B C)\end{array}$ & Grant et al. (1990) \\
\hline S17-1 & thi-1 endA1 hsdR17 supE44 $\lambda^{-}$pro & Simon et al. (1983) \\
\hline \multicolumn{3}{|l|}{ Plasmids } \\
\hline pGEM3 + & E. coli plasmid for in vitro transcription, $\mathrm{Ap}^{\mathrm{r}}$ & Promega \\
\hline pGEMamt & $0.5 \mathrm{~kb}$ internal amt fragment in pGEM $3+$ & Jakoby et al. (2000) \\
\hline pGEMamtB & $1.0 \mathrm{~kb}$ internal $a m t B$ fragment in pGEM3 + & Jakoby et al. (2000) \\
\hline pJC1 & E. coli/C. glutamicum shuttle vector, $\mathrm{Km}^{\mathrm{r}}$ & Cremer et al. (1990) \\
\hline pJCAmtBam & $3 \mathrm{~kb} \mathrm{BamHI}$ fragment carrying ' $p p c \sec B$ amt in pJC1 & This study \\
\hline pJCAmtHII & $2 \mathrm{~kb}$ HindII/Bam HI fragment carrying amt in pJC1 & This study \\
\hline pK19mobsacB & ori $\mathrm{pUC}, \mathrm{Km}^{\mathrm{r}}, m o b s a c B$ & Schäfer et al. (1994) \\
\hline pK19mobsacB-del2 & Vector for internal deletion in the $a m t B$ gene & This study \\
\hline pK19mobsacB $\Delta \mathrm{dppc}$ & $\begin{array}{l}2 \mathrm{~kb} \text { BamHI fragment with internal amt deletion in } \\
\text { pK19mobsacB }\end{array}$ & This study \\
\hline pUCamtB & pUC18 carrying a $2 \cdot 4 \mathrm{~kb}$ 'fts $Y$ amtB $g \ln K$ fragment & Jakoby et al. (1999) \\
\hline pUCamtB-del2 & $\begin{array}{l}\text { pUC18 carrying a 'fts Y glnK fragment for an internal } \\
\text { deletion in } a m t B\end{array}$ & This study \\
\hline pUCdppc & $\begin{array}{l}3 \mathrm{~kb} \text { Bam HI fragment carrying 'ppc secB amt in pUC18, } \\
\mathrm{Ap}^{\mathrm{r}}\end{array}$ & Siewe et al. (1996) \\
\hline $\mathrm{pUC} \Delta \mathrm{dppc}$ & $\begin{array}{l}2 \mathrm{~kb} B a m \mathrm{HI} \text { fragment with internal amt deletion in } \\
\text { pUC18, Ap }{ }^{\mathrm{r}}\end{array}$ & This study \\
\hline
\end{tabular}

$\mathrm{Ap}^{\mathrm{r}}$, resistance to ampicillin; $\mathrm{Km}^{\mathrm{r}}$, resistance to kanamycin. 
intervals over a period of $1.5 \mathrm{~min}$. The cells were separated from the surrounding medium by rapid filtration, washed twice and subjected to scintillation counting. The effect of mercurials was determined as described by Siewe et al. (1996).

Extraction of C. glutamicum cells and TLC. Nitrogen-starved cells were incubated in the presence of ${ }^{14} \mathrm{C}$-labelled methylammonium as described above with the exceptions that a higher cell density was used $\left(\mathrm{OD}_{600}\right.$ approx. 7$)$ and that the specific activity of the approach was increased to $12.5 \mathrm{kBq}$. Filtered cells were extracted in $4 \mathrm{ml} 0.05 \%$ SDS $/$ hot $70 \%$ ethanol solution ( $1 \mathrm{~h}$ at room temperature) immediately after the washing steps. After $10 \mathrm{~min}$ incubation the ethanolic extracts were dried at room temperature under a steady stream of air and subjected to TLC. Samples were separated on cellulose plates with a mixture of n-butanol, acetic acid and water $\left(4: 1: 1\right.$ by vol). The ${ }^{14} \mathrm{C}$-labelled products were detected either by autoradiography using Kodak X-OMAT films or BAS-MP 2025 imaging plates and a Bio-Imaging Analyzer BAS-1800 (Fuji).

Measurement of ammonium. Decrease of ammonium in the medium was measured using an ammonia-selective electrode (Orion Research). Cells were starved of nitrogen for $3 \mathrm{~h}$ to induce the synthesis of Amt and AmtB and to deplete the internal nitrogen pools. Subsequently, $200 \mu \mathrm{M}$ ammonium chloride was added to the cultures $\left(\mathrm{OD}_{600}\right.$ approx. 5) and at different times cells and culture supernatant were separated by rapid filtration using glass fibre filters (Millipore). The ammonium uptake rate was calculated from the decrease of ammonia determined in the culture filtrate.

Molecular biology techniques. For plasmid isolation, transformation and cloning, standard techniques were used (Ausubel et al., 1987; Sambrook et al., 1989). Southern blotting was carried out with digoxigenin-labelled probes using the DIG-labelling and detection kit as recommended by the supplier (Roche Diagnostics).

RNA preparation and Northern hybridization analysis. Total RNA was prepared after disruption of the C. glutamicum cells by glass beads using the RNeasy Mini Kit as recommended by the supplier (Qiagen). The RNA was either size-fractionated using agarose gels containing formaldehyde and blotted onto positively charged nylon membranes (Sambrook et al., 1989), or spotted directly onto nylon membranes using a Schleicher \& Schuell Minifold I Dot Blotter. Hybridization of digoxigenin-labelled RNA probes was detected with a Fuji luminescent image analyser LAS1000 or Kodak X-OMAT $\mathrm{X}$-ray films using alkaline phosphatase conjugated antidigoxigenin Fab fragments and CSPD as light-emitting substrate as recommended by the supplier (Roche Diagnostics).

Construction of deletion mutants. A chromosomal deletion of the amt gene was introduced in the C. glutamicum genome according to the protocol described by Schäfer et al. (1994) using plasmid pK19mobsacB for deletion in C. glutamicum and E. coli strain S17-1 for conjugation. For this purpose a $1080 \mathrm{bp}$ AocI/KspI fragment was removed from plasmid pUCdppc. After treatment with DNA polymerase I (Klenow fragment) and re-ligation, a $2 \mathrm{~kb} B a m \mathrm{HI}$ fragment was isolated from plasmid pUC $\Delta \mathrm{dppc}$ and ligated to BamHI-restricted and dephosphorylated pK19mobsacB DNA. The resulting plasmid, pK19mobsacBAdppc, was used for the chromosomal deletion via two independent recombination events as described by Schäfer et al. (1994).

To inactivate $a m t B$, an internal fragment of this gene was removed from plasmid pUCamtB by $E c o R V / B s m I$ restriction.
After blunting of the linearized plasmid DNA by mung bean nuclease treatment and re-ligation, a DNA fragment carrying the flanking regions of the deletion was isolated from the corresponding plasmid, pUCamtB-del2, by EcoRI/BamHI restriction and used further as described above. The different deletions were verified by PCR using primers annealing at flanking regions (data not shown). In addition, chromosomal DNA of the deletion strains was amplified via PCR and sequenced using the ABI Prism BigDye Terminator Cycle Sequencing Ready Reaction Kit and an ABI 310 automated sequencer (PE Applied Biosystems) to verify that the flanking DNA regions of the different deletions were not impaired during the recombination events.

\section{RESULTS}

\section{Characterization of the C. glutamicum Amt system}

To reinvestigate the transport activity of Amt in $C$. glutamicum, an amt deletion strain, MJ2-38, was constructed. When this strain was characterized in transport experiments using low concentrations of methylammonium (final concentrations $100 \mu \mathrm{M}$ and lower), only a very low uptake rate of approximately $0.5 \mathrm{nmol}$ (mg dry weight) ${ }^{-1} \mathrm{~min}^{-1}$ was detected. A similar result was obtained by Siewe et al. (1996), when methylammonium uptake in the amt gene disruption strain $\mathrm{Amt}^{-}$was studied. This background activity was also observed in de-energized or heat-inactivated cells (data not shown) and corresponds to passive diffusion. Uptake of methylammonium in strain MJ2-38 could be restored by transformation with plasmids pJCAmtBam and pJCAmtHII, carrying the C. glutamicum amt gene (Fig. 1), whilst transformation with plasmid pJC1, the vector without the amt gene, had no effect. Taken

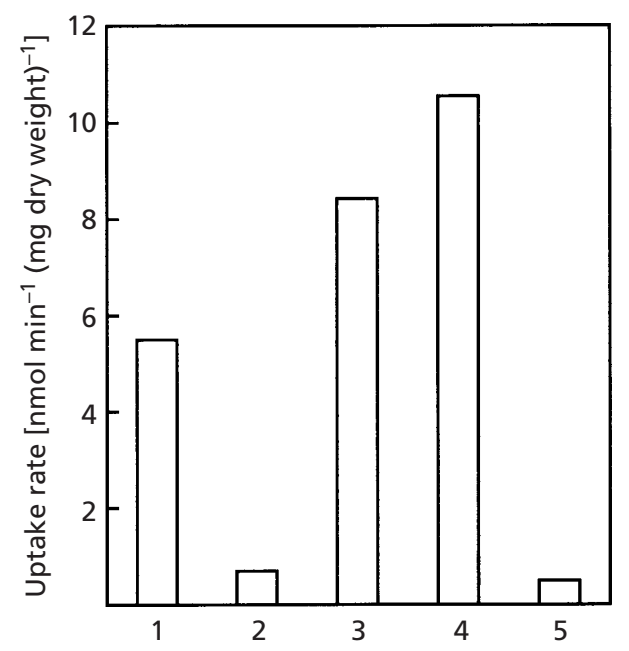

Fig. 1. Methylammonium uptake rates of different $C$. glutamicum strains. To induce expression of the amt gene, cells were incubated for $3 \mathrm{~h}$ in minimal medium without nitrogen source. Uptake was started by the addition of $\left[{ }^{14} \mathrm{C}\right]$ methylammonium $(100 \mu \mathrm{M}$ final concentration). 1, Wildtype; 2, MJ2-38; 3, MJ2-38 pJCAmtBam; 4, MJ2-8 pJCAmtHII; $5, \mathrm{MJ} 2-38 \mathrm{pJC} 1$. 

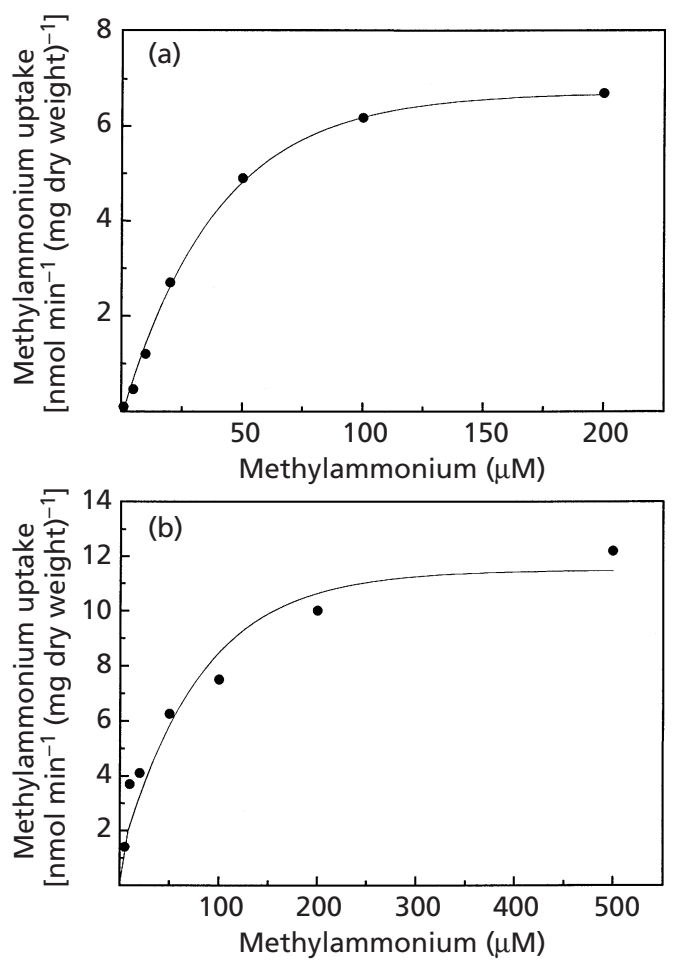

Fig. 2. Kinetic analysis of methylammonium transport depending on $\mathrm{pH}$. (a) $\mathrm{pH} 6.0$, (b) $\mathrm{pH} 8.5$. The experiments were carried out as described by Siewe et al. (1996).

together, these results indicate that Amt is the only high-affinity methylammonium uptake system in C. glutamicum.

\section{Kinetic analysis of (methyl)ammonium uptake by Amt}

Soupene et al. (1998) proposed that ammonia $\left(\mathrm{NH}_{3}\right)$, but not ammonium $\left(\mathrm{NH}_{4}^{+}\right)$is transported by Amt/Mep systems. To define the transported substrate species for the C. glutamicum Amt system, methylamine/ammonia or (methyl)ammonium, the $K_{\mathrm{m}}$ of the Amt transporter for methylammonium was determined at $\mathrm{pH} 6.0$ and 8.5 (Fig. 2). Since methylammonium $\left(\mathrm{CH}_{3} \mathrm{NH}_{3}^{+}\right)$has a $\mathrm{pK}$ of $10 \cdot 65$, the concentration of methylamine $\left(\mathrm{CH}_{3} \mathrm{NH}_{2}\right)$ changes in this range by a factor of 300 , whereas that of methylammonium remains more or less constant. As a consequence, the apparent $K_{\mathrm{m}}$ of the transporter as related to the total amount of methylamine and methylammonium, respectively, should change drastically in the case of (methyl)amine transport, whereas it should remain constant in the case of (methyl)ammonium being the substrate. An apparent $K_{\mathrm{m}}$ of Amt for methylammonium of $53 \pm 11 \mu \mathrm{M}$ was directly calculated by non-linear fitting from the uptake kinetics at $\mathrm{pH} 6.0$ and of $47 \pm 8 \mu \mathrm{M}$ at $\mathrm{pH} 8 \cdot 5$. These results are identical to those obtained by Siewe et al. (1996) who reported a $K_{\mathrm{m}}$ of $44 \pm 7 \mu \mathrm{M}$ at $\mathrm{pH} 7 \cdot 0$. Since no change in the apparent $K_{\mathrm{m}}$ was observed, it was concluded that (methyl)-

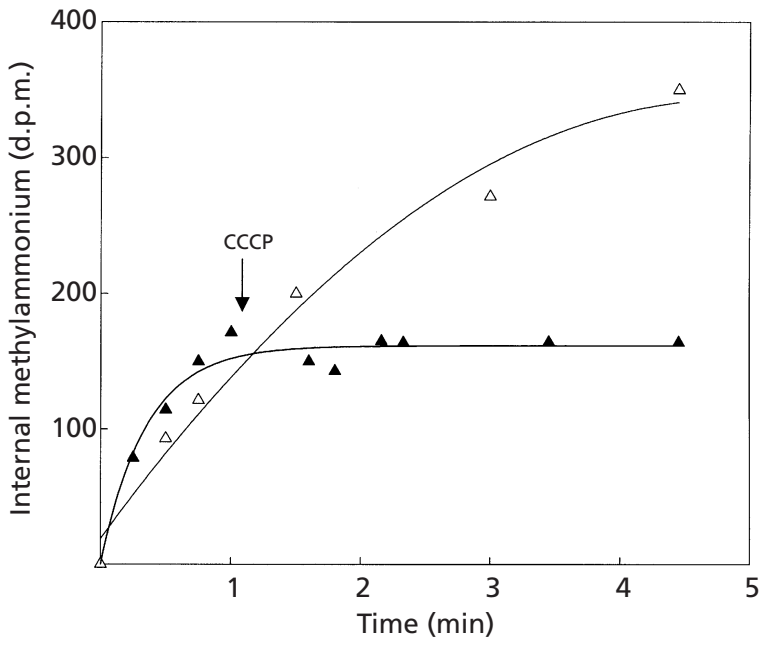

Fig. 3. Influence of CCCP on methylammonium uptake. $\triangle$, control culture without addition of CCCP; $\boldsymbol{\Delta}$, response of methylammonium uptake upon addition of CCCP (indicated by an arrow).

ammonium and not (methyl)amine is transported by the corynebacterial Amt system.

\section{Inhibition of (methyl)ammonium uptake by the uncoupler CCCP}

A linear dependence of methylammonium transport on the actual electrical potential in the range from 25 to $150 \mathrm{mV}$ was found previously (Siewe et al., 1996) by applying potassium diffusion potentials in the presence of valinomycin. To further elaborate the energy dependence of the transport reaction catalysed by Amt, we investigated the influence of the protonophor carbonyl cyanide $m$-chlorophenylhydrazone (CCCP). The observed instant uptake inhibition after its addition (Fig. 3), favours a membrane-potential-driven mechanism of (methyl)ammonium transport by Amt rather than facilitated diffusion. It was previously shown for $C$. glutamicum that under the experimental conditions used, CCCP primarily leads to inhibition of secondary transport, whilst the ATP pool of the cells and primary transport systems stay unaffected for several minutes (Krämer \& Lambert, 1990; Krämer et al., 1990).

\section{Metabolism of methylammonium}

When methylammonium is transported into the cell via Amt, the question arises whether it is metabolized in the cytoplasm, in particular since Soupene et al. (1998) proposed metabolism as being the only driving force for methylammonium uptake. While Tachiki et al. (1983) observed a small but significant turnover of methylammonium in in vitro measurements, we found none (Siewe et al., 1996). In the latter study, however, an acid cell lysis method was used, which may have led to the degradation of products of methylammonium metab- 


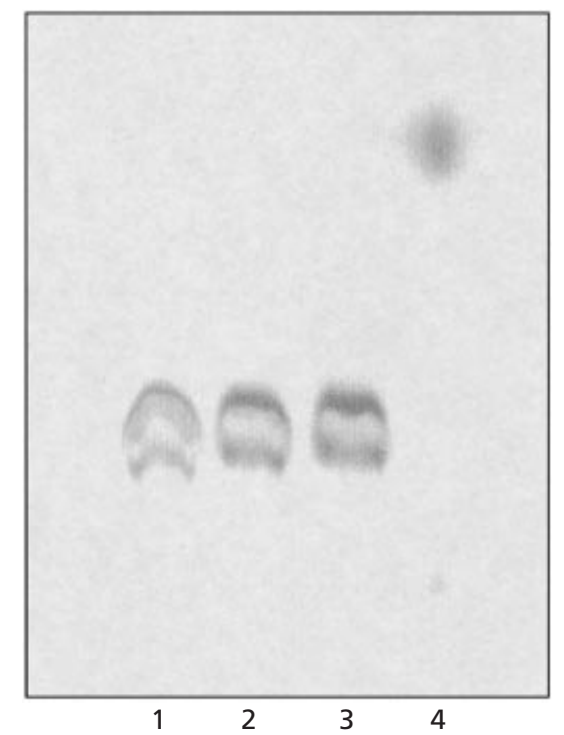

Fig. 4. TLC of ethanolic extracts of nitrogen-starved C. glutamicum cells incubated with $\left[{ }^{14} \mathrm{C}\right]$ methylammonium. Lanes: $1-3$, cells extracted after $0.5,1$ and 1.5 min incubation with $\left[{ }^{14} \mathrm{C}\right]$ methylammonium, respectively; 4, control $\left[{ }^{14} \mathrm{C}\right]-$ methylammonium.

olism. To avoid acid treatment, nitrogen-starved wildtype cells incubated with $\left[{ }^{14} \mathrm{C}\right]$ methylammonium were extracted in $70 \%$ ethanol, and the extract was dried under a steady air stream at room temperature. More than $90 \%$ of label from the extracts was recovered using this method, whilst lyophilization or heating of the sample led to a loss of label. In contrast to the previous studies (Tachiki et al., 1983; Siewe et al., 1996), we found that methylammonium is immediately metabolized by C. glutamicum, as detected by autoradiography (Fig. 4). In E. coli, methylammonium was shown to be converted to 5 - $N$-methylglutamine, most likely by glutamine synthetase (Soupene et al., 1998). In C. glutamicum, glutamine synthetase I is at the least not the only enzyme converting this compound. When thinlayer chromatograms of cell extracts from $g \ln A$ deletion strain MJ4-26 incubated with $\left[{ }^{14} \mathrm{C}\right]$ methylammonium were analysed, metabolism of this compound was still observed (data not shown), although this strain is auxotrophic for glutamine and exhibits no glutamine synthetase activity (Jakoby et al., 1997). Due to these results, and in contrast to our previous model (Siewe et al., 1996), an accumulation of (methyl)ammonium in C. glutamicum cannot be deduced from an accumulation of label.

\section{Inhibition of methylammonium transport by different amines}

Since methylammonium was found to be metabolized in C. glutamicum, the question concerning the physiological range of substrates of Amt arises. Therefore,

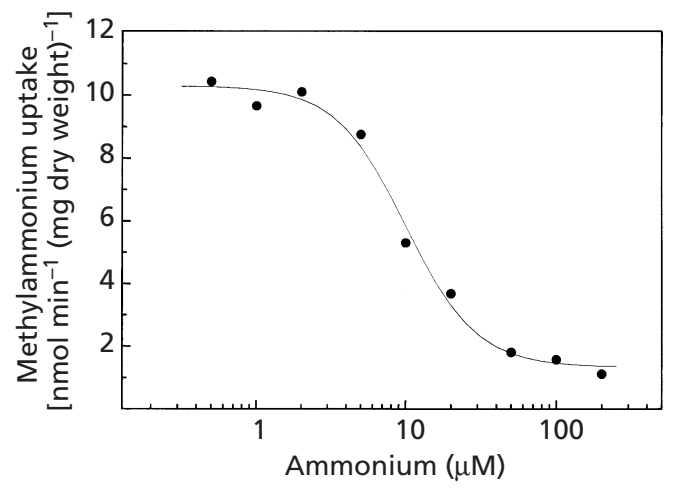

Fig. 5. Inhibition of $\left[{ }^{14} \mathrm{C}\right]$ methylammonium uptake by ammonium. Cells were incubated as described in Methods with the exception that $0,0.5,1,2,5,10,20,50,100$ or $200 \mu \mathrm{M}$ ammonium was added together with $50 \mu \mathrm{M}\left[{ }^{14} \mathrm{C}\right]-$ methylammonium.

competition assays were carried out. When $50 \mu \mathrm{M}$ methylammonium was used in the uptake assay together with increasing amounts of ammonium, the methylammonium uptake rate decreased depending on the ammonium concentration. An inhibition of $50 \%$ was reached when $10 \mu \mathrm{M}$ ammonium was added under these conditions and transport was almost completely abolished in the presence of $50 \mu \mathrm{M}$ ammonium (Fig. 5). These data indicate that ammonium is the natural substrate of Amt.

To define the substrate specificity of Amt in more detail, methylammonium uptake was determined in the presence of a 50-fold excess of different putative competitors. The uptake rates for $\left[{ }^{14} \mathrm{C}\right]$ methylammonium decreased to $3.0 \pm 0 \%$ when unlabelled methylammonium was added as a control. Addition of a 50-fold excess of dimethylamine led to a reduction of $65 \pm 2 \%$, whilst trimethylamine and tetramethylamine were not inhibitory. When the influence of ethylamine, propylamine and butylamine on methylammonium uptake was tested, only the addition of ethylamine reduced transport rates significantly. Propylamine and butylamine led to partial permeabilization of the cell membranes. Under the growth conditions tested, none of these compounds was used as sole nitrogen source in C. glutamicum (data not shown). In addition, methylammonium was not metabolized by C. glutamicum as sole carbon and energy source as also shown for other bacteria (Large, 1980). Further studies might address the question of whether these substances can be used as a co-substrate together with other nitrogen or carbon sources.

\section{Regulation of amt transcription depending on the medium $\mathrm{pH}$}

As shown recently, amt transcription is derepressed upon nitrogen starvation (Jakoby et al., 2000). On the assumption that C. glutamicum Amt facilitates trans- 


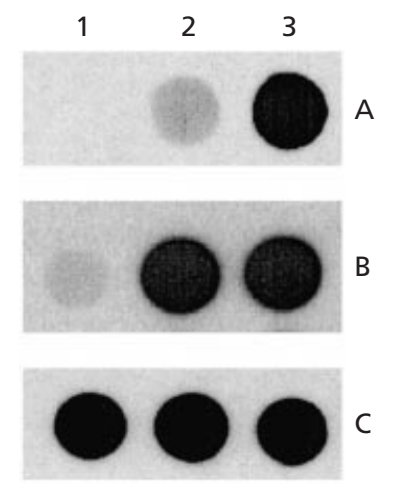

Fig. 6. Expression of the amt genes. Northern hybridizations were carried out, using total RNA prepared from strain ATCC 13032, $5 \mathrm{~min}$ before the onset of nitrogen starvation (1), or 20 min after the beginning of starvation in medium adjusted to $\mathrm{pH} 6.0$ (2) and $\mathrm{pH} 7.0$ (3), respectively. $\mathrm{A}$, amt anti-sense probe; $B, a m t B$ anti-sense probe; $C, 16 \mathrm{~S}$ rRNA probe as control.

port of ammonia rather than catalysing ammonium transport, its expression should be increased in low $\mathrm{pH}$ medium, since diffusion of ammonia across the membrane would become limiting under these conditions. Northern hybridization experiments were carried out using total RNA isolated from nitrogen-starved cells incubated at $\mathrm{pH} 6 \cdot 0$ and $7 \cdot 0$. When hybridized against an amt antisense probe, RNA isolated from cells incubated at pH 6.0 showed only a faint signal as compared with RNA prepared from cells incubated at $\mathrm{pH} 7 \cdot 0$, whilst the amount of $16 \mathrm{~S}$ rRNA in these samples stayed constant (Fig. 6). These data do not indicate an increased expression of amt at low $\mathrm{pH}$ and are thus in accord with the model that Amt works as a (methyl)ammoniumrather than a (methyl)amine-uptake system.

\section{Role of the AmtB system}

We recently isolated and sequenced a paralogue of the amt gene, amtB (Jakoby et al., 1999). When we tested transcription of the $a m t B$ gene, we found that its expression is, as with amt transcription, repressed under nitrogen excess (Jakoby et al., 2000) and derepressed upon nitrogen starvation (Fig. 6). In contrast to amt transcription, no influence of the external $\mathrm{pH}$ was observed.

From the measurements obtained during the comparison of wild-type and amt deletion strain MJ2-38, it was assumed that amtB might encode a low-affinity permease, since no high-affinity methylammonium uptake was observed in strain MJ2-38. In this case, methylammonium would be transported in the $C$. glutamicum cells via both a high-affinity uptake system, Amt, and a low-affinity carrier, AmtB, a scenario which is similar to the situation in the cyanobacterium Synechocystis PCC 6803 (Montesinos et al., 1998).

To investigate the basic kinetic parameters of AmtB and a possible regulation depending on the nitrogen availability, cells of strain MJ2-38 were starved for nitrogen sources and the rate of methylammonium uptake was determined using $1 \mathrm{mM}\left[{ }^{14} \mathrm{C}\right]$ methylammonium. However, methylammonium uptake could never be observed in strain MJ2-38 either without or with nitrogen starvation for up to $4 \mathrm{~h}$ (data not shown).

\section{Deletion of the amtB gene}

Since AmtB was obviously not directly involved in methylammonium transport, we speculated that this protein might have a regulatory function. Recently, a sensor function was discussed for the yeast (methyl)ammonium transporter Mep2 (Lorenz \& Heitman, 1998). Moreover, an interaction of the different yeast Mep systems was proposed (Marini et al., 2000). These observations led to the hypothesis that $C$. glutamicum AmtB might interact with Amt to regulate transport activity. However, when methylammonium uptake was determined in the $a m t B$ deletion mutant LN1.1 , no difference between wild-type and $a m t B$ deletion mutant was observed. Upon nitrogen starvation, a methylammonium uptake rate of $10 \cdot 8 \pm 1 \cdot 3 \mathrm{nmol}(\mathrm{mg}$ dry weight $)^{-1} \min ^{-1}$ was observed in the wild-type ATCC 13032 and 11.0 $\pm 1 \cdot 0 \mathrm{nmol}(\mathrm{mg} \text { dry weight })^{-1}$ $\min ^{-1}$ in $a m t B$ deletion strain LN-1.1. Also, regulation of the level of Amt activity was not impaired. When glutamine was added, in both strains a decrease in transport rate of $14 \%$ was observed within $10 \mathrm{~min}$ (data not shown). Together, these results demonstrate that $\mathrm{AmtB}$ is not involved in Amt regulation.

\section{Effect of pH on growth at different ammonium concentrations}

As a more physiological approach to studying the function of Amt and AmtB and to investigate which of the different concepts for ammonium acquisition holds true for C. glutamicum, we carried out growth experiments. Based on the fact that at low $\mathrm{pH}$ the concentration of the unprotonated ammonia is extremely low, diffusion and uptake should become limiting if ammonia is the transported substrate species (Soupene et al., 1998). As a result, a difference in growth of wild-type and amt deletion mutants is expected in the case of ammonia being transported as proposed for $E$. coli AmtB (Soupene et al., 1998). C. glutamicum wildtype strain ATCC 13032, amt deletion strain MJ2-38, $a m t B$ deletion LN-1.1 and $a m t / a m t B$ double deletion $\mathrm{LN}-1.2$ were grown at various ammonium concentrations $\left(0 \cdot 1,0.5,1.0\right.$ and $\left.5.0 \mathrm{mM} \mathrm{NH}_{4} \mathrm{Cl}\right)$ in minimal medium adjusted to different $\mathrm{pH}$ values $(\mathrm{pH} 6 \cdot 0,6 \cdot 5,7 \cdot 0$, $7 \cdot 5)$. No significant difference in the growth rate of the different C. glutamicum strains depending on $\mathrm{pH}$ and ammonium concentration was detected, although the final optical densities were found to depend directly on the amount of ammonium added (data not shown). This result led us to investigate whether ammonium depletion results in a decreased growth rate in C. glutamicum at 




Fig. 7. Ammonium uptake in C. glutamicum depending on the presence of Amt-type transporters: $\square$, wild-type ATCC 13032; $O$, amt deletion strain MJ2-38; $\triangle$, amtB deletion strain LN-1.1; $\boldsymbol{\nabla}$, amt/amtB double deletion LN-1.2. Experiments were carried out in duplicate and mean values are shown.

all. In fact, when cells were incubated in the absence of any nitrogen source, for a short time a similar growth rate as compared to nitrogen-supplemented cells was observed before cell division ceased completely. Obviously, C. glutamicum is able to circumvent the effects of ammonium limitation on the growth rate found in other bacteria (e.g. E. coli; see Soupene et al., 1998) by using intracellularly stored nitrogen sources like glutamate and glutamine. Up to $200 \mathrm{mM}$ internal glutamate (Krämer \& Lambert, 1990) and $50 \mathrm{mM}$ internal glutamine (Tesch et al., 1999) have been determined in C. glutamicum cells grown in minimal medium. As a consequence, growth experiments seem not to be an appropriate tool to discriminate the physiological role of Amt and AmtB.

\section{Measurement of ammonium uptake}

To circumvent the problems arising from the high internal glutamate and glutamine pools in C. glutamicum, depletion of ammonium was directly determined in the culture supernatants of strains ATCC 13032, MJ2-38, LN-1.1 and LN-1.2 (Fig. 7). Ammonium chloride $(200 \mu \mathrm{M})$ was added to nitrogen-starved cells $\left(\mathrm{OD}_{600}\right.$ approx. 5) and ammonium concentrations were determined. From the linear part of the decrease, an uptake rate of approximately $11 \mathrm{nmol}(\mathrm{mg} \text { dry weight })^{-1}$ $\min ^{-1}$ was calculated for the wild-type, which perfectly correlates with the methylammonium uptake rates measured. The transport rates obtained for amt mutant strain MJ2-38 and amtB mutant LN-1.1 were found to be about 10 and $9 \mathrm{nmol}(\mathrm{mg} \text { dry weight })^{-1} \mathrm{~min}^{-1}$, respectively, and thus not significantly lower. Interestingly, for the double mutant a biphasic decrease of ammonium in the supernatant was observed. First, ammonium decreased with a rate of approximately $8 \mathrm{nmol}$ (mg dry weight $)^{-1} \mathrm{~min}^{-1}$ until uptake ceased at a concentration of $70 \mu \mathrm{M}$ ammonium. This result cannot be explained by diffusion alone, since diffusion should depend linearly on the transmembrane concentration difference, and therefore hints of the presence of an additional ammonium uptake system.

In summary, the data obtained indicated (i) that a defect of Amt can be complemented by AmtB and vice versa, (ii) that $\mathrm{AmtB}$ is a high-affinity, ammonium-specific transport system, and (iii) that an additional (lowaffinity) ammonium uptake system might be present in C. glutamicum.

\section{DISCUSSION}

In this work (methyl)ammonium transport via two C. glutamicum permeases, Amt and AmtB, was investigated. The data of Siewe et al. (1996) and those presented here indicate that the actual transport substrate of Amt in C. glutamicum is not methylamine/ ammonia but (methyl)ammonium, which is taken up by a membrane-potential-driven mechanism. Five lines of evidence support this idea. First, a linear dependence of methylammonium transport and electrical potential in the range $25-150 \mathrm{mV}$ was found (Siewe et al., 1996), which makes facilitated diffusion of ammonia in C. glutamicum unlikely. Second, the instant uptake inhibition after addition of CCCP favours membranepotential-dependent transport by C. glutamicum Amt rather than facilitated diffusion as supposed for the $E$. coli AmtB carrier (Soupene et al., 1998). Third, and most importantly, the apparent $K_{\mathrm{m}}$ of Amt for methylammonium of approximately $50 \mu \mathrm{M}$ was not changed when measured at both $\mathrm{pH} 6.0$ and 8.5 . The measured $K_{\mathrm{m}}$ is furthermore identical at $\mathrm{pH} 7 \cdot 0$ to that previously obtained by Siewe et al. (1996). This result is only in accord with uptake of (methyl)ammonium and not of methylamine/ammonia. Fourth, the $K_{\mathrm{m}}$ of the $C$. glutamicum glutamine synthetase with respect to ammonium was determined earlier to be in the range 1.1-5.0 mM (Tachiki et al., 1981, 1983). Our own experiments (J. Meier-Wagner, unpublished results) and experiments carried out by Tachiki et al. (1983) indicated that the $K_{\mathrm{m}}$ of this enzyme for methylammonium is even higher. The affinity of the metabolizing enzyme is thus at least two orders of magnitude lower than that of the carrier protein Amt, which showed a $K_{\mathrm{m}}$ of approximately $50 \mu \mathrm{M}$ for methylammonium. The fact that the kinetic properties of ammonium uptake and glutamine synthetase activity are so dramatically different suggests that action of 
glutamine synthetase is not the major driving force for (methyl)ammonium uptake in C. glutamicum. This is in accord with the observation that methylammonium is metabolized even in the absence of glutamine synthetase I. Fifth, studies on the regulation of amt expression showed that synthesis of Amt is dramatically diminished at $\mathrm{pH} 6 \cdot 0$, which is in contrast to the expected synthesis of an ammonia facilitator.

Whilst Amt is the main uptake system, transporting (methyl)ammonium with high affinity into the cell, AmtB obviously does not contribute to the uptake of methylammonium but is an ammonium-specific permease. Whether ammonium or ammonia is the actual substrate species transported by AmtB was not determined. A similar set of ammonium transport proteins was found in Rhodobacter sphaeroides, where an ammonium-specific uptake system together with a methylammonium/ammonium permease was found (Cordts \& Gibson, 1987), and in Arabidopsis thaliana where AMT1 proteins transport (methyl)ammonium (Gazzarrini et al., 1999) whilst AtAMT2 is ammoniumspecific (Sohlenkamp et al., 2000). Furthermore, the kinetic results of ammonium uptake studies indicated the presence of an additional, low-affinity ammonium transport system in C. glutamicum.

In summary, membrane-potential-driven transport of (methyl)ammonium was shown for the C. glutamicum Amt system. This type of uptake mechanism might also hold true for other bacteria. In physiological terms, moreover, energy-dependent uptake of ammonium makes sense especially for organisms living in acid environments, in which almost no ammonia is present.

\section{ACKNOWLEDGEMENTS}

The authors are grateful to Gregor Wersch for excellent technical assistance. This work was supported by the Fonds der Chemischen Industrie.

\section{REFERENCES}

Abe, S., Takayama, K. \& Kinoshita, S. (1967). Taxonomical studies on glutamic acid-producing bacteria. J Gen Microbiol 13, 279-301.

Ausubel, F. M., Brent, R., Kingston, R. E., Moore, D. D., Seidman, J. G., Smith, J. A. \& Struhl, K. (1987). Current Protocols in Molecular Biology. New York: Greene Publishing Associates and Wiley Interscience.

Cordts, M. L. \& Gibson, J. (1987). Ammonium and methylammonium transport in Rhodobacter sphaeroides. J Bacteriol 169, 1632-1638.

Cremer, J., Eggeling, L. \& Sahm, H. (1990). Cloning the dapA dapB cluster of the lysine-secreting bacterium Corynebacterium glutamicum. Mol Gen Genet 220, 478-480.

Gazzarrini, S., Lejay, L., Gojon, A., Ninnemann, O. \& Frommer, W. B. (1999). Three functional transporters for constitutive, diurnally regulated, and starvation-induced uptake of ammonium into Arabidopsis roots. Plant Cell 11, 937-947.

Grant, S. N. G., Jessee, J., Bloom, F. R. \& Hanahan, D. (1990).
Differential plasmid rescue from transgenic mouse DNAs into Escherichia coli methylation-restriction mutants. Proc Natl Acad Sci U S A 87, 4645-4649.

Jakoby, M., Tesch, M., Sahm, H., Krämer, R. \& Burkovski, A. (1997). Isolation of the Corynebacterium glutamicum glnA gene encoding glutamine synthetase I. FEMS Microbiol Lett 154, 81-88.

Jakoby, M., Krämer, R. \& Burkovski, A. (1999). Nitrogen regulation in Corynebacterium glutamicum: isolation of genes involved and biochemical characterization of the corresponding proteins. FEMS Microbiol Lett 173, 303-310.

Jakoby, M., Nolden, L., Meier-Wagner, J., Krämer, R. \& Burkovski, A. (2000). AmtR, a global repressor in the nitrogen regulation system of Corynebacterium glutamicum. Mol Microbiol 37, 964-977.

Jayakumar, A., Hong, J.-S. \& Barnes, E. M., Jr (1986). Feedback inhibition of ammonium (methylammonium) ion transport in Escherichia coli by glutamine and glutamine analogs. J Bacteriol 169, 553-557.

Keilhauer, C., Eggeling, L. \& Sahm, H. (1993). Isoleucine synthesis in Corynebacterium glutamicum: molecular analysis of the $i l v B$ ilvN-ilvC operon. J Bacteriol 175, 5595-5603.

Kleiner, D. (1985). Bacterial ammonium transport. FEMS Microbiol Rev 32, 87-100.

Kleiner, D. (1993). $\mathrm{NH}_{4}^{+}$transport systems. In Alkali Cation Transport Systems in Prokaryotes, pp. 379-395. Edited by E. P. Bakker. Boca Raton, FL: CRC Press.

Kleiner, D. \& Castorph, H. (1982). Inhibition of ammonium (methylammonium) transport in Klebsiella pneumoniae by glutamine and glutamine analogues. FEBS Lett 146, 201-203.

Krämer, R. \& Lambert, C. (1990). Uptake of glutamate in Corynebacterium glutamicum. 2. Evidence for a primary active transport system. Eur J Biochem 194, 937-944.

Krämer, R., Lambert, C., Hoischen, C. \& Ebbighausen, H. (1990). Uptake of glutamate in Corynebacterium glutamicum. 1. Kinetic properties and regulation by internal $\mathrm{pH}$ and potassium. Eur $J$ Biochem 194, 929-935.

Large, P. J. (1980). Microbial growth on methylated amines. In Microbial Growth on $\mathrm{C}_{1}$ Compounds, pp. 55-69. Edited by $\mathrm{H}$. Dalton. London/Philadelphia/Rheine: Heyden.

Lorenz, M. C. \& Heitman, J. (1998). The MEP2 ammonium permease regulates pseudohyphal differentiation in Saccharomyces cerevisiae. EMBO J 17, 1236-1247.

Marini, A.-M., Springael, J.-Y., Frommer, W. B. \& André, B. (2000). Cross-talk between ammonium transporters in yeast and interference by the soybean SAT1 protein. Mol Microbiol 35, 378-385.

Montesinos, M. L., Muro-Pastor, A. M., Herrero, A. \& Flores, E. (1998). Ammonium/methylammonium permeases of a cyanobacterium. J Biol Chem 273, 31463-31470.

Sambrook, J., Fritsch, E. F. \& Maniatis, T. (1989). Molecular Cloning: a Laboratory Manual, 2nd edn. Cold Spring Harbor, NY : Cold Spring Harbor Laboratory.

Schäfer, A., Tauch, A., Jäger, W., Kalinowski, J., Thierbach, G. \& Pühler, A. (1994). Small mobilizable multi-purpose cloning vectors derived from the Escherichia coli plasmids pK18 and pK19: selection of defined deletions in the chromosome of Corynebacterium glutamicum. Gene 145, 69-73.

Siewe, R. M., Weil, B., Burkovski, A., Eikmanns, B. J., Eikmanns, M. \& Krämer, R. (1996). Functional and genetic characterization of the (methyl)ammonium uptake carrier of Corynebacterium glutamicum. J Biol Chem 271, 5398-5403. 
Simon, R., Priefer, U. \& Pühler, A. (1983). A broad host range mobilization system for in vivo genetic engineering: transposon mutagenesis in Gram-negative bacteria. Appl Microbiol Biotechnol 1, 784-791.

Sohlenkamp, C., Shelden, M., Howitt, S. \& Udvardi, M. (2000). Characterization of Arabidopsis AtAMT2, a novel ammonium transporter in plants. FEBS Lett 467, 273-278.

Soupene, E., He, L., Yan, D. \& Kustu, S. (1998). Ammonia acquisition in enteric bacteria: physiological role of the ammonium/methylammonium transport B (AmtB) protein. Proc Natl Acad Sci U S A 95, 7030-7034.

Tachiki, T., Wakisaka, S., Suzuki, H., Kumagai, H. \& Tochikura, T. (1981). Glutamine synthetase from Micrococcus glutamicus: effect of nitrogen sources in culture medium on enzyme formation and some properties of crystalline enzyme. Agric Biol Chem 45, 287-292.

Tachiki, T., Wakisaka, S., Suzuki, H., Kumagai, H. \& Tochikura, T.
(1983). Variation of Micrococcus glutamicus glutamine synthetase brought about by divalent cations. Agric Biol Chem 47, 287-292.

Tesch, M., de Graaf, A. A. \& Sahm, H. (1999). In vivo fluxes in the ammonium-assimilatory pathways in Corynebacterium glutamicum studied by ${ }^{15} \mathrm{~N}$ nuclear magnetic resonance. Appl Environ Microbiol 65, 1099-1109.

Thomas, G., Coutts, G. \& Merrick, M. (2000). The glnKamtB operon, a conserved gene pair in prokaryotes. Trends Genet 16, $11-14$.

von Wirén, N., Gazzarrini, S., Gojon, A. \& Frommer, W. B. (2000). The molecular physiology of ammonium uptake and retrieval. Curr Opin Plant Biol 3, 254-261.

Received 26 July 2000; revised 25 September 2000; accepted 4 October 2000. 